\title{
Framework for the Joint Development of Hydrocarbon Resources
}

\author{
Robert Beckman and Leonardo Bernard*
}

\section{Introduction}

The Exclusive Economic Zone (EEz) regime under Part v of the 1982 United Nations Convention of the Law of the Sea (UNCLOS) ${ }^{1}$ grants coastal States exclusive rights to explore and exploit the natural resources, whether living and non-living (including minerals and hydrocarbon resources), of the seabed and its subsoil, and sovereign rights with regard to other activities for the economic exploitation of the zone. The EEz may extend up to 200 nautical miles (M) from the territorial sea baseline. ${ }^{2}$ When the EEz regime was established by the Third United Nations Conference on the Law of the Sea, ${ }^{3}$ it placed 87 per cent of the world's known offshore hydrocarbon fields under coastal State jurisdiction. ${ }^{4}$ This prompted coastal States to maximize their maritime zones claims, either through EEz claims or through extended continental shelf claims.

In situations where there are a number of claimants with maritime claims to the same geographic area, it may be difficult for the disputes to be resolved through negotiation, especially if sovereignty disputes over land territory are

* In writing the present article, we have drawn on some works which have been published in Beckman, et al, (eds.), Beyond Territorial Disputes in the South China Sea: Legal Framework for the Joint Development of Hydrocarbon Resources (2013), especially works by Gavin Maclaren and Rebecca James, Negotiating Joint Development Agreements, at 139-144 and by David Ong, Implications of Recent Southeast Asian State Practice for the International Law on Offshore Joint Development, at 192-193.

1 United Nations Convention on the Law of the Sea, 10 December 1982, 1833 UNTS 3 (entered into force 16 November 1994) [UNCLOS]. As of 19 February 2013, UNCLOS has 165 parties (including the European Union), with Timor Leste being the most recent State to accede on 8 January 2013.

2 UnClos, ibid, Art. 56(1)(a).

3 The conference held its first session in 1973, and worked for several months each year until it finally adopted a convention in 1982 .

4 United Nations, The United Nations Convention on the Law of the Sea (A Historical Perspective), available at http://www.un.org/Depts/los/convention_agreements/convention_historical _perspective.htm.

(C) ROBERT BECKMAN AND LEONARDO BERNARD, 2019 | DOI:10.1163/9789004379633_006 This is an open access article distributed under the terms of the prevailing CC-BY-NC License at the time of publication. 
also involved. The possibility of offshore hydrocarbon deposits being situated in areas of overlapping claims adds to the complexity of the disputes. In order to exploit these hydrocarbon resources, petroleum companies need to be confident that their investment will not be adversely affected by uncertainty as to which State or entity has jurisdiction to grant licenses or leases in the area. A long period of legal stability is therefore essential for petroleum companies.

This article demonstrates that international law imposes certain rights and duties in relation to exploitation of hydrocarbon resources in overlapping claim areas. These rights and duties constrain the conduct of the claimants in their exploration and exploitation of such resources. It argues that under both UNCLOS and general international law, States are obliged to cooperate with each other in the management of resources in overlapping claim areas, either through Joint Development Arrangements (JDAs) or other forms of provisional arrangements pending resolution of the maritime boundaries. The article then sets out the legal framework for JDAs for the exploration and exploitation of hydrocarbon resources under UNCLOS, before examining the preparation process and the circumstances in which joint development may be desirable. It also discusses the various models for JDAs. Finally, the article concludes with an overview of the challenges facing JDAS.

II

UNCLOS and JDAS

UNCLOS establishes a legal framework to govern all uses of the oceans. It has no provisions on how to resolve sovereignty disputes over offshore features. However, it does contain provisions on the nature and extent of the maritime claims that can be made from land territory and offshore features. Under UNCLOS, coastal States have sovereignty over their land territory as well as over a $12 \mathrm{M}$ belt of sea adjacent to their coast called the territorial sea, ${ }^{5}$ albeit this is subject to the passage regimes in UNCLOS and to other rules of international law. ${ }^{6} \mathrm{~A}$ coastal State is also entitled to a contiguous zone extending out to $24 \mathrm{M}$ from the baselines from which the territorial sea is measured. ${ }^{7}$ In the

5 UNCLOS, supra note 1, Arts. 2 and 3.

6 UNCLOS, supra note 1, Art. 17. Article 17 provides that the ships of all States have a right of innocent passage through the territorial sea.

7 UNCLOS, supra note 1, Art. 33. 
contiguous zone, a coastal State has the right to enforce violations of its customs, fiscal, immigration and sanitary laws. ${ }^{8}$

One of most important features of UNCLOS is that it gives coastal States sovereign rights to explore and exploit natural resources adjacent to its territorial sea in two resource zones - the EEZ and the continental shelf. First, coastal States have the right to establish an EEZ extending to $200 \mathrm{M}$ from the baselines from which their territorial sea is measured. ${ }^{9}$ In the EEZ, a coastal State has sovereign rights for the purpose of exploring and exploiting the living and non-living natural resources of the seabed and its subsoil and of the waters superjacent to the seabed. ${ }^{10}$

Second, coastal States also have sovereign rights to explore and exploit the natural resources of the continental shelf.1 ${ }^{11}$ The extent of a coastal State's continental shelf was one of the most heavily debated topics during the negotiations in the Third UN Conference on the Law of the Sea. The Conference finally agreed to a $200 \mathrm{M}$ limit from the coastline. ${ }^{12}$ However, States with a broad continental shelf off their coasts, through a complex assessment mechanism, may extend their sovereign rights claim to the resources of their continental shelf up to $35^{\circ} \mathrm{M}$ from their coastline or to the outer edge of the continental margin..$^{13}$ Claims to an extended continental shelf beyond $200 \mathrm{M}$ (referred to as "outer continental shelf"), however, must be submitted to and accepted by the Commission on the Limits of the Continental Shelf (CLCS). ${ }^{14}$

As mentioned above, UNCLOS also allows States to claim maritime zones from islands under their sovereignty. Article 121(1) defines an "island" as "a naturally formed area of land, surrounded by water, which is above water at high tide". ${ }^{15}$ Islands which are capable of sustaining human habitation or an economic life of their own are entitled to a territorial sea, contiguous zone, EEZ and continental shelf.16 "Rocks" fall within the definition of an island.

$8 \quad$ UNCLOS, supra note 1, Art. 33 (1).

$9 \quad$ UNCLOS, supra note 1, Art. 57.

$10 \quad$ UNCLOS, supra note 1, Art. 56.

11 UNCLOS, supra note 1, Art. 77.

12 UNCLOS, supra note 1, Art. 76(1).

13 UNCLOS, supra note 1, Art. 76(5).

14 UNCLOS, supra note 1, Art. 76(8); as of May 2013, 65 countries have put in their submissions to the CLCS, and the CLCS has issued 18 recommendations. See, Submissions, through the Secretary-General of the United Nations, to the Commission on the Limits of the Continental Shelf, pursuant to Article 76, paragraph 8, of the United Nations Convention on the Law of the Sea of 10 December 1982, available at http://www.un.org/depts/los/ clcs_new/commission_submissions.htm.

15 UNCLOS, supra note 1, Art. 121(1).

16 UNCLOS, supra note 1, Art. 121(2). For further discussion on rocks and islands, see The Republic of the Philippines v. The People's Republic of China, Award on the Merits of 12 July 2016, at 204-260, available at http://www.pcacases.com/web/view/7. 
However, Article 121(3) provides that rocks which cannot sustain human habitation or economic life of their own shall have no EEZ or continental shelf. ${ }^{17}$

\section{A}

UNCLOS Provisions on Boundary Delimitation and Provisional Arrangements

The drafters of UNCLOS recognized that there would be instances where claims to maritime space would overlap. UNCLOs therefore has provisions on the delimitation of overlapping territorial sea, ${ }^{18} \mathrm{EEZ}^{19}$ and continental shelf claims. ${ }^{20}$ For purposes of this article, the provisions on delimitation of the EEZ and continental shelf are the most salient. Articles 74(1) and 83(1), which are identical, state that:

The delimitation of the [continental shelf/EEZ] between States with opposite or adjacent coasts shall be effected by agreement on the basis of international law, as referred to in Article 38 of the Statute of the International Court of Justice, in order to achieve an equitable solution.

Over the subsequent years, international courts and tribunals have attempted to articulate the method by which the delimitation should be determined in order to reach an equitable solution. Some international courts and tribunals have described the method provided for in UNCLOS Articles 73 and 84 as the "equitable principles-relevant circumstances method". ${ }^{21}$ In the Libya/Malta decision, the ICJ explained that the equidistance method may be applied if it leads to an equitable solution.22 The ICJ went further in the Qatar/Bahrain decision, stating that for the delimitation of maritime zones beyond $12 \mathrm{M}$, it would first draw a provisional equidistance line before considering whether there are circumstances that require an adjustment of that line. ${ }^{23}$

In the 2009 Black Sea Case between Romania and Ukraine, the ICJ introduced a three stage approach to maritime delimitation: (i) establish a provisional equidistance line; (ii) consider whether there any factors which call for

\footnotetext{
17 UNCLOS, supra note 1, Art. 121(3).

18 UNCLOS, supra note 1, Art. 15.

19 UNCLOS, supra note 1, Art. 74.

20 UNCLOS, supra note 1, Art. 83.

21 See, for example, Land and Maritime Boundary between Cameroon and Nigeria (Cameroon v. Nigeria; Equatorial Guinea intervening) [2002] ICJ Reports 303 at para. 288.

22 Continental Shelf (Tunisia/Libyan ArabJamahiriya, (1982) ICJ Reports, at para. 62 [Tunisia/ Libya].

23 Maritime Delimitation and Territorial Questions between Qatar and Bahrain, Merits, Judgment (2001) ICJ Reports 40, at para. 176.
} 
an adjustment of the equidistance line to reach an equitable result; and (iii) verify that that line does not lead to an inequitable result by reason of any marked disproportion between the ratio of the respective coast lengths and the ratio between the relevant maritime area of each State by reference to the delimitation line. ${ }^{24}$ The International Tribunal for the Law of the Sea (ITLOS) also confirmed this approach as the preferred method for delimitation of the EEZ and continental shelf in its recent decision regarding delimitation of the EEZ and outer continental shelf between Bangladesh and Myanmar. ${ }^{25}$

However, while international case law has attempted to clarify the international rules governing the delimitation of maritime boundaries, there is still room for differing interpretations as to how to draw the provisional median line and which factors should be taken into account in order to adjust that provisional median line. The inherent nature of the sovereign rights of the coastal States over their continental shelf adds to the problems of delimiting areas of overlapping claims, ${ }^{26}$ since all such claims over continental shelf are presumably valid due to the coastal States' inherent sovereign rights. ${ }^{27}$ Thus, States have a choice between settling the boundary, which may require long negotiations during which time the resources of the disputed area are not exploited, and cooperating to jointly develop the resources while setting aside the boundary dispute. ${ }^{28}$

\section{B Nature of Obligation to Negotiate "Provisional Arrangements of a Practical Nature"}

UNCLOS caters for the fact that it may be extremely difficult for States to reach agreement in areas of overlapping EEZ and continental shelf claims; and it purports to provide a temporary solution to this situation in paragraph 3 of Articles 74 and 83 . These interim solutions include a moratorium on resource exploitation pending final delimitation and an obligation on States concerned

24 Maritime Delimitation in the Black Sea (Romania v Ukraine) (2009) ICJ Reports 61, at paras. 116-122.

25 Dispute Concerning Delimitation of the Maritime Boundary between Bangladesh and Myanmar in the Bay of Bengal (2012) Judgment, ITLos Case No 16 [Bangladesh/Myanmar] at para. 455, available at http://www.itlos.org/fileadmin/itlos/documents/press_releases _english/PR.140-E.pdf.

26 Prosper Weil, The law of Maritime Delimitation - Reflections 9-14 (1989).

27 Peter C. Reid, Petroleum Development in Areas of International Seabed Boundary Disputes: Means for Resolution 8 OIL \& GAS LAW \& TAXATion REvieW 214, 215 (1984-85).

28 Fox et Al, Joint Development of Offshore Oil and Gas: A Model Agreement FOR States With EXPlanatory COMMENTARY 39 (1989). 
to take every effort to make "provisional arrangements" in the interim. ${ }^{29}$ It provides that if delimitation cannot be effected by agreement:

[T] he States concerned, in a spirit of understanding and cooperation, shall make every effort to enter into provisional arrangements of a practical nature and, during the transitional period, not to jeopardize or hamper the reaching of the final agreement. Such arrangements shall be without prejudice to the final delimitation. ${ }^{30}$

Provisional arrangements under UNCLOS share a common goal with the provisional measures powers of the United Nations Security Council, this being to prevent aggravation of a situation in dispute. ${ }^{31}$ The provision is designed to "promote interim regimes and practical measures that could pave the way for provisional utilization of disputed areas pending delimitation" and "constitutes an implicit acknowledgement of the importance of avoiding the suspension of economic development in a disputed maritime area". 32

There are three aspects to the obligation contained in UNCLOS Articles 74(3) and 83(3). First, States should make every effort to enter into provisional arrangements of a practical nature. This imposes on parties a "duty to negotiate in good faith" 33 and to take "a conciliatory approach to negotiations in which they would be prepared to make concessions in the pursuit of a provisional arrangement". ${ }^{34}$ Second, during this transitional period before there is final agreement on the boundaries, States are obliged not to jeopardize or hamper the reaching of a final agreement on delimitation. International courts and tribunals have found that any activity which represents an irreparable prejudice to the final delimitation agreement is a breach of this obligation. ${ }^{35}$ Third, provisional arrangements of a practical nature are "without prejudice to the final delimitation". ${ }^{36}$

29 Ibid., at 34 .

$30 \quad$ UNCLOS, supra note 1, Arts. 74(3) and 83(3); Guyana/Suriname Arbitration, UN Law of the Sea Annex VII Arb Trib, award on 17 September 2007, at para. 461, available at http:// www.pca-cpa.org/upload/files/Guyana-Suriname\%2oAward.pdf; see also, Ranier Lagoni, Interim Measures Pending Maritime Delimitation Agreements, 78 AJIL 345 (1984) at 358.

31 United Nations, Charter of the United Nations, 24 October 1945, 1 UNTS XVI, Art. 40, available at http://www.unhcr.org/refworld/docid/3ae6b393o.html.

32 Guyana/Suriname Arbitration, supra note 30, at para. 460.

33 Ibid., para. 460.

34 Ibid., at paras. 471-478.

35 Ibid., at para. 480.

36 UnCLOS, supra note 1, Arts. 74(3) and 83(3); Guyana/Suriname Arbitration, supra note 30; see also, Lagoni, supra note 30 , at 358 . 
The obligation of States to make every effort to enter into provisional arrangements of a practical nature has been succinctly summarized by scholars:

The States concerned are obliged to "enter into negotiations with a view to arriving at an agreement" to establish provisional arrangements of a practical nature and ... "not merely to go through a formal process of negotiation." The negotiations are to be "meaningful, which will not be the case when either [state] insists upon its own position without contemplating any modification of it." However, the obligation to negotiate does not imply an obligation to reach agreement ...37

This view was endorsed in the 2007 arbitration between Guyana and Suriname by an Arbitral Tribunal constituted under Annex VII of UnCLOS. ${ }^{38}$ While it was acknowledged that the language "every effort" leaves "some room for interpretation by the States concerned, or by any dispute settlement body", it imposes on the parties to the dispute "a duty to negotiate in good faith". This requires the parties to take "a conciliatory approach to negotiations, pursuant to which they would be prepared to make concessions in the pursuit of a provisional arrangement". ${ }^{39}$ Further, the obligation to negotiate in good faith "is not merely a nonbinding recommendation or encouragement but a mandatory rule whose breach would represent a violation of international law".40

The second part of the obligation provides that during this transitional period States are obliged not to jeopardize or hamper the reaching of a final agreement on delimitation. It is said that a court or tribunal's interpretation of this obligation must reflect the delicate balance between preventing unilateral activities that affect the other party's rights in a permanent manner but, at the same time, not stifling the parties' ability to pursue economic development in a disputed area during a time-consuming boundary dispute. ${ }^{41}$

International courts and tribunals have found that "any activity which represents an irreparable prejudice to the final delimitation agreement" 42 is a breach of this obligation and that "a distinction is to be made between activities of the kind that lead to a permanent physical change, such as exploitation of oil and gas reserves, and those that do not, such as seismic exploration".43 For example, in the Guyana/Suriname Arbitration it was found that allowing

37 Lagoni, supra note 30 , at 356.

38 Guyana/Suriname Arbitration, supra note 30, para. 461.

39 Ibid.

$40 \quad$ Lagoni, supra note 30 , at 354.

41 Guyana/Suriname Arbitration, supra note 30, at para. 470.

42 Lagoni, supra note 30 , at 366.

43 Guyana/Suriname Arbitration, supra note 30, at para. 467. 
exploratory drilling in disputed waters was a breach of the obligation to make every effort not to hamper or jeopardize the reaching of a final agreement as this could result in a physical change to the marine environment and engenders a "perceived change to the status quo".44 This was in contrast to seismic testing, which did not cause a physical change to the marine environment.

However, it is clear that States are under no obligation to enter into any provisional arrangement but must only "make every effort" to negotiate in good faith. Articles 74(3) and 83(3) also do not mandate the type of provisional arrangements States can enter into, but leave it to the discretion of the States concerned. ${ }^{45}$ Provisional arrangements can include a wide variety of arrangements such as mutually agreed moratoriums on all activities in overlapping areas, ${ }^{46}$ joint development or cooperation on fisheries, ${ }^{47}$ joint development of hydrocarbon resources, ${ }^{48}$ agreements on environmental cooperation ${ }^{49}$ and agreements on allocation of criminal and civil jurisdiction. ${ }^{50}$ The term "arrangements" implies that the arrangement can include both informal documents such as Notes Verbale, Exchange of Notes, Agreed Minutes, or Memorandum of Understanding (MOU); as well as more formal agreements, such as treaties. ${ }^{51}$ With regard to the meaning of "a practical nature", Articles $74(3)$

44 Guyana/Suriname Arbitration, supra note 30, at para. 480.

45 Natalie Klein, Provisional Measures and Provisional Arrangements in Maritime Boundary Disputes (2006) 21 International Journal of Marine And Coastal 423, 444 (2006); see also, Sun Pyo Kim, Maritime Delimitation and Interim ArrangeMENTS in North East Asia 94 (2004).

46 Maritime Delimitation Treaty between Jamaica and the Republic of Colombia, 12 November 1993, Article 3, available at http://www.un.org/depts/los/LEGISLATIONANDTREATIES/ PDFFILES/TREATIES/JAM-COL1993MD.PDF.

47 Agreement on Fisheries between the Republic of Korea and the People's Republic of China, 3 August 2000 (entered into force 30 June 2001), reprinted in Kim, supra note 45, at 347.

48 Memorandum of Understanding between Malaysia and the Kingdom of Thailand on the Establishment of a Joint Authority for the Exploitation of the Resources in the Sea-Bed in a Defined Area of the Continental Shelf of the Two Countries in the Gulf of Thailand, 21 February 1979 (entered into force 24 October 1979), reprinted in David M Ong, Thailand/Malaysia: The Joint Development Agreement 1990, 6 International Journal of Marine AND Coastal LaW 57, 61 (1990).

49 Agreement between the Government of Jamaica and the Government of the Republic of Cuba on the Delimitation of the Maritime Boundary between the Two States, 18 February 1994, Article 5, reprinted in 34 LAw of the Sea Bulletin, Division of Ocean Affairs and the Law of the Sea, Office of Legal Affairs, United Nations, at 64.

5o Agreement between the Government of the Kingdom of Thailand and the Government of Malaysia on the Constitution and Other Matters relating to the Establishment of the Malaysia-Thailand Joint Authority, 30 May 1990.

51 KIM, supra note 45, at 47. Kim notes that "some States may prefer Mous to formal agreements for provisional arrangements because these have some advantages in several aspects: no need to publish them as these are not treaties; no need for elaborate final 
and 83(3) do not give much guidance, but have been interpreted to mean that such arrangements "are to provide practical solutions to actual problems regarding the use of an area and are not to touch upon either the delimitation issue itself or the territorial questions underlying this issue". ${ }^{2}$

The use of the word "provisional" implies that the arrangements are interim measures pending the final delimitation of maritime boundaries. ${ }^{53}$ Also, the provisional arrangements are "without prejudice" to the final delimitation of the maritime boundary. This means that nothing in the arrangement can be deemed as a renunciation of the claim of any party to sovereignty over the features or sovereign rights in the surrounding waters. Also, the provisional arrangement does not constitute an explicit or implicit acknowledgement of the legitimacy of the claim of any other party. ${ }^{54}$

\section{Joint Development Arrangements as a "Provisional Arrangement"}

The concept of joint development of hydrocarbon resources appears to have emerged in the $1950{ }^{5} .{ }^{5}$ However, despite considerable State practice since that time, there is no common or uniform definition of joint development of hydrocarbon resources. ${ }^{56}$ It is usually used as a "generic term" 57 and extends from unitization of a single resource straddling an international boundary to joint development of a shared resource where boundary delimitation is shelved

clauses or the formalities surrounding treaty-making; easy amendment; and no need to be submitted for an approval of the parliament"; see also, Lagoni, supra note 30.

52 Lagoni, supra note 30 , at 358 .

53 Lagoni, supra note 30 , at 356.

54 See for example, Treaty between Australia and the Republic of Indonesia on the Zone of Cooperation in an Area between the Indonesian Province of East Timor and Northern Australia, 11 December 1989 [1991] ATs 9, Article 2(3), (entered into force 9 February 1991) [Timor Gap Treaty]; generally, see also, Gao Zhiguo, Legal Aspects of Joint Development in International Law, in M Kusuma-Atmadja, T Mensah and B Oxman (eds.), Sustainable Development and the Preservation of the Oceans: The Challenges of unclos And Agenda 21, Proceedings of the Law of the Sea Institute's Twenty-Ninth Annual Conference, Denpasar, Bali, Indonesia, 19-22 June 1995, 639 (1997).

55 Fox et al, supra note 28 , at 54 .

56 Thomas Mensah, Joint Development Zones as an Alternative Dispute Settlement Approach in Maritime Boundary Delimitation, in Ranier Lagoni and Daniel Vignes (eds.), Maritime Delimitation 143-153, 146 (2006). For example, Mensah states that "some scholars seek to distinguish between, on the one hand, 'unitization of shared resources' which they describe as an arrangement under which 'a single resource straddling an international boundary is developed subsequent to agreement without reference to such boundary' and on the other, joint development properly so called which they define as 'a regime under which the entire boundary dispute is set aside, thus creating an ambient development of political cooperation from the outset."

57 Fox et al, supra note 28 , at 43 . 
because it is not feasible or possible to reach agreement on a boundary at the time.

There is no doubt that JDAs are a type of "provisional arrangement of a practical nature". Their legal basis stems from Articles 74(3) and 83(3) of UNCLOs. Indeed, they appear to be the most commonly used arrangements for overlapping claim areas. International courts and tribunals have also endorsed joint development agreements as an alternative to maritime delimitation. ${ }^{58}$ For example, in the North Sea Continental Shelf Cases, the ICJ held that joint exploration agreements were "particularly appropriate when it is a question of preserving the unity of a deposit" in areas of overlapping claims. ${ }^{59}$ In his dissenting opinion in the 1982 continental shelf delimitation case between Tunisia and Libya, Judge ad hoc Evensen proposed a system of joint exploration of petroleum resources based on his view that joint development represented an alternative equitable solution to the maritime boundary dispute which was eventually adopted by the parties. ${ }^{60}$ In the Eritrea/Yemen Arbitration, the Arbitral Tribunal stated that the parties should give every consideration to the shared or joint or unitized exploitation of any such resources. ${ }^{61}$

There has been considerable doctrinal debate on whether there exists an obligation to enter into JDAs. ${ }^{62}$ However, while JDAs are a useful mechanism, it appears clear that States do not have a specific duty to enter into JDAs in areas of overlapping claims. First, there is no provision in UNCLOS which specifies this obligation. Articles 74(3) and 83(3) leave it to the discretion of the States as to what type of provisional arrangement they enter into and, again, the States are merely under an obligation to negotiate in good faith. Article 123 provides that States bordering an enclosed or semi-enclosed sea should cooperate with each other, but it imposes no "specific and legally enforceable" obligation on these States, as its language is more "exhortatory than obligatory". ${ }^{63}$ Also, the call for cooperation in Article 123 is limited to conservation of marine living

58 Guyana/Suriname Arbitration, supra note 30, at para. 463.

59 North Sea Continental Shelf Sea Cases (Federal Republic of Germany/Denmark; Federal Republic of Germany/Netherlands), 1969 ICJ 4, at para. 99.

6o Ong, supra note 48 , at 787 .

61 The Government of the State of Eritrea $v$ The Government of the Republic of Yemen (1999), 119 ILR at 417, (1999), Award Of the Arbitral Tribunal in The Second Stage of the Proceedings (Maritime Delimitation), available at http://www.pca-cpa.org/showpage. asp?pag_id=1160.

62 For a summary of the two opposing schools of thought, see, Chidinma Bernadine Okafor, Joint Development: An Alternative Legal Approach to Oil and Gas Exploitation in the Nigeria-Cameroon Maritime Boundary Dispute? 21(4) INTERNATIONAL Journal of MARINE AND CoAstal LAW 506-509 (2006).

63 Ong, supra note 48 , at 781 . 
resources, protection of the marine environment and coordination of marine scientific research. It does not include the joint development of hydrocarbon resources. ${ }^{64}$

Second, there is no obligation in customary international law to enter into joint development agreements. Customary international law consists of State practice, which must be both constant and uniform and common to a significant number of States, particularly those States whose interests are specially affected, and there must be opinio juris in that States must recognize that this practice constitutes law binding on them. ${ }^{65}$ While there is arguably widespread State practice on joint development in many areas of the world, it does not appear to be constant or uniform. Nor does it appear to be a result of the fact that States believe they are under a legal obligation to enter into such agreements. ${ }^{66}$

The lack of status of joint development as solution to maritime boundary disputes under customary international law, however, does not necessarily indicate a legal void. ${ }^{67}$ There is a strong argument to be made that States have a general obligation to cooperate in the exploitation of shared natural resources, even if the normative content of this rule is yet to be determined. ${ }^{68}$ Indeed, cooperation to manage and exploit shared marine resources may be a better solution for settling overlapping maritime claims than waiting for an agreement to be reached after a long negotiation process. ${ }^{69}$

\section{Conditions Necessary for JDAs ${ }^{70}$}

Before negotiating a JDA, there are a number of factors that States should consider which go beyond a mere exploration of their legal rights and entitlements. Although many of these factors would not be given weight by an international

\footnotetext{
64 Ong, supra note 48 , at 782 .

65 See Martin Dixon, Textbook on International LaW 30-37 (2007).

66 Ian Townsend-Gault and William Stormont, Offshore Petroleum Joint Development Arrangements: Functional Instrument? Compromise? Obligation? in GERALD BLAKE, ET AL (eds.), The Peaceful Management of Transboundary Resources 53 (1995).

67 David Ong, Joint Development of Common Offshore Oil and Gas Deposits: 'Mere' State Practice or Customary International Law?, 93(4) AJIL 771, 792 (1999).

68 Ibid.

69 Douglas Johnston, The Theory and History of Ocean Boundary Making 227-229 (1988).

70 This section draws heavily from Gavin Maclaren and Rebecca James, Negotiating Joint Development Agreements, in Beckman, et AL, (eDS.), Beyond Territorial Disputes in the South China Sea: Legal Framework for the Joint Development of Hydrocarbon RESOURCES 139-144 (2013).
} 
court or tribunal, they will usually be significant for a State in determining its approach to negotiations. ${ }^{71}$

\section{A Recognition of Overlapping Claims ${ }^{72}$}

Understanding and recognising the overlapping claims is the important first step in considering joint development. This is because joint development does not occur in a vacuum, but proceeds in the context of the underlying strengths and weaknesses of the overlapping claims as assessed by reference to the relevant principles of public international law. ${ }^{73}$ The legitimacy of the respective States' claims under international law usually has a significant bearing upon the negotiation of the size and location of the joint development area and the revenue sharing arrangements that will apply within it. ${ }^{74}$

\section{B $\quad$ Political Will ${ }^{5}$}

The presence of political will in support of joint development in all relevant States is critical to the success of any joint development negotiation. Negotiating joint development agreements, which are often complex, requires considerable expertise and commitment of time and resources. Joint development agreements also require, almost by definition, willingness to compromise. A high level of political will within each State is necessary to achieve progress. Negotiations which proceed on the basis of ambit claims and/or aggressive posturing will almost always fail to bring about a joint development agreement. Maintaining a spirit of cooperation beyond the negotiation process is also critical as States must often work together for many years after the original agreement is struck in order to achieve the full benefits of any joint development agreement. ${ }^{76}$

\section{Domestic Political Opinion ${ }^{77}$}

If negotiations are taking place within a context of a highly charged domestic political debate, it will be more difficult for a dispute to be set aside and

71 Gavin Maclaren and Rebecca James, Negotiating Joint Development Agreements, in BECKMAN, ET AL, supra note 70, at 141.

72 Ibid, at $140-141$.

73 MacLaren and James, supra note 71 , at 140-141.

74 MacLaren and James, supra note 71 , at 140-141.

75 MacLaren and James, supra note 71, at 141-142.

76 One commentator has observed that "the intermittently coincidental political will of both Malaysia and Thailand" was "one of the mains reasons for the 11-year delay in the full implementation of the provisions of the 1979 Memorandum of Understanding”; see Ong, supra note 48 , at 221.

77 Maclaren and James, supra note 71, at 142. 
opportunities for joint development to be agreed upon. This is sometimes the case where sovereignty over particular geographic features is in issue. In such circumstances it is not uncommon for domestic political parties to seize upon maritime issues as part of their domestic political agenda, for public opinion to become entrenched against cooperation, and for national governments to use nationalistic sentiment as part of their negotiating strategy. The domestic political landscapes of the States in question and broader issues pertaining to the relationships between neighbouring States will therefore be highly relevant. ${ }^{78}$

\section{Other Factors}

$1 \quad$ Historical factors ${ }^{79}$

Historical factors are often relevant to the negotiation and conclusion of a joint development agreement. The legacy of past military action, disputes over sovereignty of particular features or a history of failed negotiations, among many other things, can make the process of achieving joint development far more difficult.

\section{$2 \quad$ Economic factors ${ }^{80}$}

Economic factors can be critical to a State's approach to joint development. While the presence of oil concessions or oil wells within a disputed area would not be taken into consideration in its own right in a maritime delimitation determination, ${ }^{81}$ the nature, extent and location of hydrocarbon resources may be critical to a State when considering its approach to joint development negotiations.

A State's domestic need for hydrocarbon resources may prove to be an influential factor which adds impetus to jointly developing a potentially prospective area. ${ }^{82}$ Accordingly, States should develop an understanding of the

78 Okafor, supra note 62 , at $510-512$.

79 Maclaren and James, supra note 71, at 142.

8 Ibid.

81 The ICJ and Permanent Court of Arbitration have found that oil concessions and oil wells are not in themselves to be considered as relevant circumstances justifying the adjustment or shifting of a provisional delimitation line, though they may be taken into account if based on express or tacit agreement between the parties (which may indicate a consensus on the maritime areas to which they are entitled): see further, Land and Maritime Boundary between Nigeria and Cameroon (Cameroon v Nigeria: Equatorial Guinea intervening) (Judgment) [2002] ICJ Rep 303, 447-448 [304]; Barbados $v$ The Republic of Trinidad and Tobago (Award of $n$ August 2006) at 108-109, [364] available at http://www .pca-cpa.org/showpage.asp?pag_id=1152.

82 Okafor, supra note 62, at 512. See for example the now defunct Timor Sea Treaty between the Government of East Timor and the Government of Australia, East Timor-Australia, signed 20 May 2002, 2258 UNTS 3. 
relevant economic resource potential of the area of overlap and the potential location of those resources. However, it must also be kept in mind that the greater the degree of knowledge about the geological potential of the joint development area, the greater the risk that States will make expansive claims and be less willing to compromise. ${ }^{83}$

If resources are primarily located in an area to which one State considers it has a particularly strong (or defensible) claim, this will tend to result in that State pushing for a smaller joint development area which leaves it with direct control over those resources, or for a joint development agreement that provides it with a disproportionate share of the benefits of joint development. The other State is likely to be equally determined to expand the size of the joint development area to include the relevant resources and to seek the greatest possible share of those resources.

\section{$3 \quad$ Availability of third party dispute resolution ${ }^{84}$}

Where compulsory third party dispute resolution is available, it is often the case that one State will decide to achieve a final delimitation through these means. This is because in any given set of circumstances, one State will often consider that, having regard to the strengths and weaknesses of the claims and the location of resources, it will obtain a superior outcome through delimitation rather than joint development.

4

Number of States involved ${ }^{85}$

It is typically more difficult to resolve multilateral disputes through joint development than bilateral disputes. Most joint development agreements to date have been bilateral, though in principle a joint development agreement need not be limited to two States.

As is evident from the above discussion, various factors should be considered when assessing whether joint development is a viable option in the circumstances surrounding a particular dispute. It is also evident that politically motivated activities and nationalist sentiments described above diminish the

83 One example of this is that "negotiations for the Timor Sea Treaty were made more complex in light of the discovery of two fields, known as Greater Sunrise, that straddle the JPDA across the eastern limits," in Report Number 6-2o(1) and (2) -Australia-East Timor, in DA Colson and RW Smith (eds.), International Maritime Boundaries, Volume V 3806, 3808 (2005). See also, Okafor, supra note 62, at 513.

84 Maclaren and James, supra note 71, at 143. Compare this, however, with the compulsory conciliation under Annex v of UnCLOs. See for example the Report and Recommendations of the Compulsory Conciliation Commission between Timor-Leste and Australia on the Timor Sea, Conciliation Commission, 9 May 2018.

85 Maclaren and James, supra note 71, at 144. 
prospects of achieving a successful joint development agreement, and should be avoided.

Once States have decided to explore joint development as a possible solution to delimitation disputes, a further range of issues, such as the possible form of the joint development agreement, should be explored. Each dispute is different and there is no precise formula for States to adhere to when determining their approach.

\section{Form and Content of JDAs}

Once States that have overlapping claims acknowledge that the best way for them to reach an agreement is by entering into some form of JDA, there are several issues that need to be addressed during the negotiation process. First, the claimant States need to ensure that their national positions would not be jeopardized by agreeing to enter into the JDA. Second, the negotiating States need to identify the areas that are to be jointly developed. Third, the negotiating States need to agree on the form and extent of the JDA.

\section{A Without Prejudice}

It is important to note that entering into a JDA is the second best option for States; having a defined maritime boundary being the first preferred option. Thus, it is natural that all parties to the JDA wish to preserve their respective legal positions. ${ }^{86}$ As noted above, JDAs as provisional arrangements of a practical nature are "without prejudice to the final delimitation". ${ }^{87}$ The "without prejudice" provision ensures that whatever arrangement agreed to will not affect the final boundary agreement. This means that if a State makes concessions in order to agree to a JDA, the concessions cannot be used against it in any negotiations or adjudication to reach a final maritime boundary agreement. A JDA gives the States the opportunity to exploit the hydrocarbon resources without giving up their claims to sovereignty or sovereign rights in the joint development area. Furthermore, it is important to remember that although a JDA is a provisional measure, it usually lasts for 20 or 30 years or even longer. Thus, agreeing to a JDA in effect means shelving the dispute for a generation or two, while enabling the States to benefit from the exploitation of the hydrocarbon resources in the agreed area.

86 David Anderson, Modern law of the Sea: Selected Essays 495 (2008).

87 UNCLOS, supra note 1, Articles 74(3) and 83(3); Guyana/Suriname Arbitration, supra note 30; see also, Lagoni, supra note 30 , at $35^{8}$. 


\section{B Identifying the Area to be Jointly Developed ${ }^{88}$}

One of the major obstacles in concluding JDAs is the difficulty of the claimants agreeing on a geographic area/s that can be subject to joint development. JDAs tend to be concluded in areas where there are clearly defined overlapping claims, for example, in an overlapping EEz or continental shelf claim..$^{89}$ It is typically the case that each State must at a minimum clarify the extent of, and the rationale for, its claim by reference to principles of public international law..$^{90}$ It is almost impossible to make significant progress without doing so. The agreed area of the joint development zone will either cover the entirety of the overlapping EEZ or continental shelf claim ${ }^{91}$ or will be an area within the overlapping claim area..$^{92}$ There are examples of States refusing to clearly articulate the limits of their maritime claims. Often this type of conduct is perceived as a negotiating tactic by other States and can become a stumbling block preventing further progress. ${ }^{93}$

From the process of analysing and testing each relevant State's claim, a consensus must emerge regarding the location, size and shape of the area to be jointly developed. ${ }^{94}$ The joint development area should be as small as possible, as having a joint development agreement is a second best outcome where claimant States have failed to reach an agreement on fixing the maritime boundaries between them, but agree on a practical accommodation for a certain period of time. ${ }^{95}$ The duration may be tied to the duration of the offshore activities. Generally, between the initial seismic work and the completion of

88 Maclaren and James, supra note 71, at 144-145.

89 See Tara Davenport, et al., Conference Report, Conference on Joint Development and the South China Sea Organized by the Centre for International Law, 16 - 17 June 2011, available at http://cil.nus.edu.sg/wp/wp-content/uploads/2011/o6/Report-of-CIL-Conference-on -Joint-Development-and-the-South-China-Sea-2011-04.08.2011.pdf.

9o Maclaren and James, supra note 71, at 144.

91 The Malaysia-Thailand Joint Development Area consists of the entirety of the overlapping claims between Malaysia and Thailand: See, the 1979 Memorandum of Understanding between Malaysia and Thailand on the Establishment of a Joint Authority for the Exploitation of the Resources of the Sea-bed in a Defined Area and the 1990 Agreement between the Government of Malaysia and the Government of the Kingdom of Thailand on the Constitution and Other Matters Relating to the Establishment of the Malaysia-Thailand Joint Authority.

92 See, for example, the 2008 Principled Consensus on the East China Sea Issue, where the area identified for joint development only consisted of a part of the overlapping claim area.

93 Maclaren and James, supra note 71, at 144.

94 Ibid.

95 Anderson, supra note 86, at 498. 
production to decommissioning and disposal of the installation, periods of 40 or 50 years are normal in joint development agreements. ${ }^{96}$

Following agreement on the area to be jointly developed, the next most significant issue is typically the basis on which government revenues are to be shared. In many cases, this has occurred by way of equal division of "government take." ${ }^{97}$ However, on some occasions a significant disproportion has been agreed. ${ }^{98}$

\section{Forms of a Joint Development Agreements}

A number of authors have identified three broad structural models for joint development agreements. ${ }^{99}$ In essence, these are:

\section{$1 \quad$ The single-state mode $l^{100}$}

The first joint development model examined here is arguably the simplest option available to States because it requires the least amount of effort by the governments concerned by way of formal bilateral cooperation and legal and institutional harmonization. This model comprises an agreement whereby one State manages the development of the deposits located in a disputed area on behalf of both States. The other State shares in the revenues arising from the resource exploitation, once the costs incurred by the first State have been subtracted. Several of the earliest joint development agreements utilized this model.

Of late, this model has fallen into disuse. This is principally due to the apparently unacceptable loss of autonomy on the part of the State that allows its sovereign rights to be administered by another State. Many States are reluctant to accept such a situation, especially within a disputed seabed area subject to overlapping claims. They are fearful of appearing to accept, however implicitly, a status quo that confers de facto jurisdiction to the other State, even if the de

\footnotetext{
$96 \quad$ Ibid.

97 Maclaren and James, supra note 71, at 144.

98 A good example of this is the Timor Sea Treaty between the Government of East Timor and the Government of Australia, 20 May 2002, [2003] ATs 13 (entered into force on 2 April 2003) (Timor Sea Treaty). For further examples, see Ana Bastida, et al, Cross-border Unitization and Joint Development Agreements: An International Law Perspective, 29(2) HousTON JOURNAL OF INTERNATIONAL LAW 356, 416 (2007).

99 See for example, Ong, supra note 67, at 788-792; Bastida, et al, ibid, at 416-418; Yusuf Mohammad Yusuf, Is Joint Development a Panacea for Maritime Boundary Disputes and for the Exploitation of Offshore Transboundary Petroleum Deposits?, 4 INTERNATIONAL LAW ENERGY REVIEW 130, 132-133 (2009).

100 The text in this section draws heavily from David Ong, Implications of recent Southeast Asian State practice for the international law on offshore joint development, in BECKMAN, ET AL, supra note 70, at 192-193.
} 
jure position is explicitly reserved. The main disadvantage is the other State's concern regarding the possible adverse inferences drawn from the managing State's pre-emptive role in the disputed area and its effect on the strength of the other State's claims to this area. ${ }^{101}$ However, this thesis is arguably turned on its head by the latest manifestation of a JDA in the Southeast Asian region, namely the Brunei-Malaysia arrangements established by the bilateral Exchange of Letters in 2009. That arrangement represents a return to a single State model.

\section{$2 \quad$ The joint-venture model 102}

The second joint development model is the most popular option among the three models. It comprises an agreement requiring the Parties to establish compulsory joint ventures between their national or other nominated oil companies in designated joint development zones. Alternatively, the agreement provides for the compulsory unitization of transboundary deposits and the nomination of a single operator to exploit the unitized deposit on behalf of all the interested operators. A few agreements also combine several of these features.

A number of joint venture model JDAs provide for the unitization of deposits found both within, or lying across, the boundaries of a specifically designated area of marine space. These designated joint development zones usually correspond to disputed continental shelf/EEz claims between the two States concerned. Other joint venture model JDAs require the compulsory unitization of transboundary deposits in situations where the maritime boundary has been previously agreed. This latter type of joint venture model JDAs has been renounced as not being true "joint development." 103 Despite this objection to the classification of these types of agreements as being "JDAs," we have classified them as JDAs in order to provide as many different working examples of State practice as possible. Moreover, these transboundary unitization agreements represent successful instances of international cooperation that merit examination in their own right.

Thus, it may be noted that there are two distinctive sub-species of joint venture model JDAs. The first type is agreements that designate specific joint

\footnotetext{
101 Fox et al, supra note 28 , at $149,152$.

102 Ong, supra note 100, at 196-197.

103 Kusuma-Atmadja for example argues that "joint development" properly relates only to overlapping claim areas subject to joint jurisdiction, rather than the unitization of oil and gas structures straddling the boundaries of neighbouring countries, which is merely a well-known principle in the petroleum industry. See, Mochtar Kusuma-Atmadja, Joint Development of Oil and Gas by Neighbouring Countries, in Kusuma-Atmadja, Mensah AND OXMAN, supra note 54, at 592.
} 
development zones in which compulsory joint ventures are established in respect of unitized deposits. The second type is transboundary unitization agreements that provide for a single operator to exploit a "straddling" deposit lying across a previously agreed maritime boundary. The second type is mainly found in the North Sea region.

The third joint development model is the most complex and institutionalized option, requiring a much higher level of cooperation than the previous two models. This model consists of an agreement between the interested States establishing an international joint authority or commission with legal personality, licensing and regulatory powers, and a comprehensive mandate to manage the development of the designated zone on behalf of the States. These joint authorities have been described as "strong" institutions, with extensive supervisory and decision-making powers and wide-ranging functions, as opposed to the "weak" liaison or consultative-type bodies under the direction of the parties established by a number of agreements incorporating the second joint development model, described above. ${ }^{105}$ Within the Southeast Asian maritime region as defined in this article, the 1979 and 1990 Malaysian-Thailand agreements are good examples of this third joint development model.

\section{Factors Influencing the Form of a Joint Development Agreement ${ }^{106}$}

The choice between a simple or more comprehensive joint development model will be governed, to a very significant extent, by the willingness of one State to allow another State's laws to apply within all or part of the joint development area and, consequently, for one State to have disproportionate administrative responsibility for all or part of the joint development area. Where States are prepared to apply one State's laws within the joint development area, the creation of a JDA is a much more straightforward undertaking. Most commonly, this is acceptable where one State perceives that it has a very weak claim to the relevant area, where one State has a longer history and a greater knowledge of petroleum regulation, or where the area in question is a very small portion of the continental shelf and exclusive economic zone of the relevant State.

\footnotetext{
104 Ong, supra note 100, at 200.

105 Masahiro Miyoshi, The Joint Development of Offshore Oil and Gas in Relation to Maritime Boundary Delimitation, 2 (5) International Boundaries Research Unit, MARItime BRIEFING 43-44 (1999).

106 Maclaren and James, supra note 71, at 146-149.
} 
Often neither State is prepared to allow the other to have a disproportionate level of control or influence over the joint development area. In these circumstances, it is typical to pursue a more comprehensive JDA, which involves an application of the joint authority model referred to above to the circumstances. Developing a stand-alone regime for petroleum activities becomes essential in this scenario. In essence, the States will need to ensure either that they have direct control over petroleum activities (for example, through national oil companies as proxies for each State) or that there is a framework for the regulation of petroleum activities so that investors are comfortable to invest their money. As a practical matter, this is an involved and complex process. Typically, comprehensive joint development solutions tend to be more appropriate where the area of overlap is large, petroleum exploration is required and/or where the respective claims of relevant States are equally legitimate.

Significant expertise is required to develop a stand-alone oil and gas regulatory framework in light of the complex technical issues and policy questions which need to be dealt with. Even where States have experience in regulating petroleum activities, they often will not have recent experience in establishing an oil and gas regulatory framework. Furthermore, there is potential for the interests of the States to diverge on matters that lead to asymmetries in the economic benefit that each derives from joint development. Taken together, these factors make negotiating joint development agreements time-consuming and difficult, even where there is considerable political will in support of resolution, willingness to compromise and the assistance of appropriate experts.

The presence of gas resources within an area of overlapping claims gives rise to additional complexity, and has often created problems in the implementation of joint development agreements for a number of reasons. The typical joint development model has focussed on oil. Apportionment of the benefits of oil development between States is usually achieved by a division of "government take" (in cash or in kind) at the well head and the sharing of tax revenues by each State in accordance with a pre-agreed formula. Other economic benefits of oil development, such as associated service industries, tend to accrue to the State with the greatest capacity to service the oil industry. Typically, little or no attempt is made to apportion these benefits between the States. However, gas projects require significant development downstream of the well head and there is considerable value in delivering the physical product to market. This is the case even where the gas is ultimately to be processed into LNG and exported, as the economic benefits of LNG processing are significant. The potential economic benefits of gas exploitation include infrastructure development, pipeline tariffs, employment opportunities, additional tax revenue, an increase in the value of the product onshore processing, import-offset 
benefits and enhanced energy security. Joint development agreements often do not provide for the allocation of benefits between States downstream of the well head. This creates the potential for States to disagree about the development of gas resources after the joint development agreement has been finalised and, in turn, for delays or breakdowns in implementation. It will, for instance, be difficult to have gas development plans approved and agreed where the consent of both States is required.

Consequently, it is in the interests of States to give consideration to the eventual development of gas resources in the process of negotiating a joint development agreement over gas-prone areas to avoid the potential for stalemate to arise later. One way of addressing this issue is to provide for the sharing of some of the economic benefits of downstream gas development between States through the framework of joint development. Oil companies can also play a role in this regard. In some circumstances, careful commercial structuring has allowed parties to proceed with a development in circumstances where stalemate might otherwise have arisen. ${ }^{107}$

As will be apparent, there is a trade-off to be made between negotiating a joint development agreement which seeks to provide for all eventualities and one which records agreement on key matters only. While it is easier to negotiate and record the latter, this type of agreement is accompanied by the risk of interminable delays down the track which may frustrate the anticipated benefits of joint development. 108

107 A novel compromise was reached between Australia and East Timor in respect of the Bayu Undan project. In this scenario, the energy company Conoco was successful in facilitating East Timor's approval of the Bayu Undan LNG and liquids project in Australia on the basis that it would construct and operate the gas pipeline to Australia and the LNG facility located in Darwin on a basis which provided a low "infrastructure rate of return," consequently pushing profits upstream to the well head. This benefited East Timor as it was entitled to $90 \%$ of the government revenue achieved at the well head, but was also acceptable to Australia since it obtained the employment benefits and tax revenues from the LNG facility and pipeline.

108 For instance, the first Memorandum of Understanding entered into between Thailand and Malaysia in 1979 "did not provide a sufficiently detailed legal framework for the exploration and exploitation of the petroleum resources in the Joint Development Area." The parties subsequently encountered difficulties in light of "the enormity of the task involved in attempting to come up with a new legal regime for joint development which the Joint Authority could operate in the Joint Development Area, but which also represented a viable compromise between both parties" own, incompatible, domestic petroleum development regimes"; see Ong, supra note 48, at 229-230. 


\section{E Common Provisions in Joint Development Agreements}

Regardless of the joint development model utilized in State practice, similar types of provisions can be found in most of these agreements. Such common provisions include the following: non-prejudice exceptions to the sovereign rights of each party over the disputed deposit; jurisdictional allocations; institutional arrangements and sometimes, a hydrocarbon licensing regime; dispute settlement; environmental protection; third party rights. In seeking to understand these alternatives, it is important to note that there is no need for States to draw on any specific form of joint development model. ${ }^{109}$ States are ultimately free to appropriately tailor their treaty arrangements to the circumstances of the underlying dispute, and they almost invariably do so.

There are certain terms common to many joint development agreements. These include a demarcation of the area that is covered by the joint development agreement, the basis for sharing government revenues and costs within the joint development area, the scope of activities to which the joint development agreement will apply, the applicable law to apply within the joint development area, the duration of the agreement to be entered into, how it is to be terminated and dispute resolution between the parties.

\section{Conclusions}

If a State party to UNCLOS is not able to reach an agreement through negotiations on its EEZ or continental shelf boundaries with an adjacent or opposite State, and it is not willing or able to request for an international court or tribunal to delimit the maritime boundary, certain obligations are triggered under UNCLOS. First, both States have an obligation to make every effort to enter into "provisional arrangements of a practical nature" pending a final agreement on their maritime boundary. Second, they have an obligation not to take any actions that would jeopardize or hamper the reaching of a final agreement on the maritime boundary, including the unilateral exploitation of the hydrocarbon resources in the area of overlapping claims. In such circumstances, it may be in their common interest to set aside the negotiations on the maritime boundary and consider entering into a JDA as a provisional arrangement of a practical nature. A JDA enables the two States to share the hydrocarbon resources without prejudicing their position on the final maritime boundary.

However, JDAs are not an easy solution. They are generally not possible unless several essential factors are present. First, the two States must have a

109 Yusuf, supra note 99, at 133-134. 
certain level of trust in each other. Second, they must have a common desire to set aside their competing claims and jointly develop the resources. Third, and perhaps most important, they must have the political will necessary to set aside their differences and convince their domestic audience that it is in their national interest to cooperate by sharing the natural resources. Fourth, they must agree on an area for joint development which is politically acceptable to both sides.

If these factors are present, the details of the JDA can be negotiated. Several models are available, and the legal and technical issues which must be addressed are fairly well understood. If the necessary trust and political will are present, the details can be worked out through negotiations. If they are not present, it may be in the best interests of the two States to resolve the maritime boundary by referring it to a court or tribunal. 